\title{
HEAVY METALS STATUS IN VEGETABLES AND SOIL IRRIGATED WITH WASTEWATER IN DOMIZ1 CAMP, DUHOK, KURDISTAN REGION-IRAQ.
}

\author{
RAMADHAN OMER HUSSAIN*, DILSHAD ABDULRAHMAN MOHAMMED ${ }^{* *}$ \\ *Dept. of Horticulture, College of agricultural engineering sciences, University of Duhok, Kurdistan \\ Region-Iraq. \\ ** Directorate of the Environment of Duhok City, Kurdisatn Region-Iraq.
}

(Received: September 17,2019; Accepted for Publication: February 23,2020)

\begin{abstract}
This study was conducted in Domiz1 camp, Duhok, Kurdistan Region-Iraq to estimate the levels of heavy metals accumulation in soil and vegetables irrigated with contaminated water. The concentration of $\mathrm{Pb}, \mathrm{Cd}$, Co, and $\mathrm{Zn}$ measured in soil, wastewater, and fruits of tomato (Solanum lycopersicum), of eggplant (Solanem melongena), pepper (Capsicum annum), pumpkin (Cucurbita moschata), squash (Cucrbita pepo), gourd (Lagenaria siceraria), and okra (Abelmoschus esculentus). The results showed that the concentration of $\mathrm{Pb}$, $\mathrm{Cd}, \mathrm{Co}$, and $\mathrm{Zn}$ in wastewater used for irrigation was $\left(0.001, \mathrm{ND}, 0.0015,0.058 \mathrm{mg}^{-1}\right)$ respectively; in soil was $\left(6.8,0.8,9.0\right.$, and $\left.80 \mathrm{mg}^{-\mathrm{kg}^{-1}}\right)$ respectively; and in the studied vegetables ranged from $\left(3.73-11.43 \mathrm{mg}^{-\mathrm{kg}^{-}}\right.$ 1) for $\mathrm{Pb},\left(0.22-0.59 \mathrm{mg}^{-\mathrm{kg}^{-1}}\right)$ for $\mathrm{Cd},\left(0.03-0.22 \mathrm{mg} . \mathrm{kg}^{-1}\right)$ for $\mathrm{CO}$, and $\left(38.83-65.70 \mathrm{mg}^{-\mathrm{kg}^{-1}}\right)$ for $\mathrm{Zn}$. Bio concentration factor for $\mathrm{Pb}$ was $(\mathbf{0 . 5 4 9 - 1 . 6 8 1})$, for $\mathrm{Cd}$ it was (0.271-0.733), for Co it was (0.271-0.733), and for $\mathrm{Zn}$ it was (0.485-0.821). The maximum daily intake of $\mathrm{Pb}, \mathrm{Cd}$, $\mathrm{Co}$, and $\mathrm{Zn}$ from eating the studied

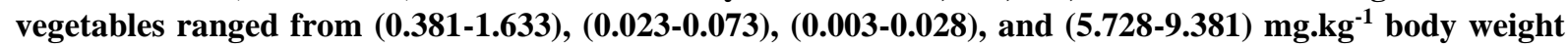
respectively.
\end{abstract}

KEYWORDS: $\mathrm{Pb}, \mathrm{Cd}, \mathrm{Co}, \mathrm{Zn}$, wastewater. Bio concentration factor and Maximum daily intake.

\section{INTRODUCTION}

V egetables are among the most important food stuffs for peoples of mostly all countries, because they are a source of very important nutritional substance such as minerals, vitamins, fibers, and antioxidant. When vegetables grown in a polluted environment, it may accumulate different toxic materials among which are heavy metals.

Municipal waste water is being used for irrigation purposes in several countries around the world due to many reasons including; large waste water availability in these countries, problems encountering the disposal, and saving fresh water for other purposes (Avci, 2013). As a result, the demands for using wastewater for irrigation purposes have been increased dramativally in recent years (Song et al., 2006). However application of waste water for irrigation leads to improve soil properties because of the organic matter and nutritional elements it contain (Ali $e t$ al., 2012). But, on the other hand, using wastewater for irrigation lead to accumulate toxic elements in the soil such as heavy metals (Kumar and Chandra, 2004).

Heavy metals are those elements that have atomic number greater than twenty and a specific gravity more than one (Lasat, 2000). They present in the environment in a very low concentration (ppm). Heavy metals are very dangerous; because they are not bioagridable, tend to accumulate in organism tissues, and magnification through food chains. Some heavy metals such as $\mathrm{Cu}$ and $\mathrm{Zn}$ are essential elements for plant growth, while others such as $(\mathrm{Pb}$, and $\mathrm{Cd}$ ) are harmful to plants and didn't incorporate in any biological process of plant cell (Parsons, 2003).

Heavy metals in soil occurs naturally from the parent materials driving and due to human activity (Bowen, 1966 \& Fytianos et al., 2001). Natural sources include (geological sources, volcanic eruptions, and aerosol of forest fires). The major anthropogenic sources of heavy metals are the burning of fossil fuels, application of

ramadhan@uod.ac 
pesticides and fertilizers, power stations, transporting, smelting, waste incineration, and recycling operations (Intawongse and Dean, 2006).

Domiz 1 camp is one of the several camps in Kurdistan Region-Iraq, which was built to accommodate the Syrian refuges. The camp located in the Domiz area that belong to Semel district, Duhok city, Kurdistan Region-Iraq. The camp was established on April, 2012. There are 6397 families in the camp which contains 28698 individuals of the two genders (BRHA, 2019). The majority of these families are with agricultural expertise, some of them grow some vegetables using the wastewater of the camp for the irrigation. Therefore this study was conduct to determine the validity of this water for irrigation in terms of heavy metals accumulation in all of soil, water, and plant.

\section{MATERIALS AND METHODS \\ Study site}

The present study was conducted in summer of the year 2018 on some vegetables fields in Domiz1 camp. Domiz1 camp elevation is ( $406 \mathrm{~m}$ ) (Latitude: $36^{\circ} 46{ }^{\prime} 59.4$ 'N) and (Longitude: $\left.42^{\circ} 52^{\prime} 52.9^{\prime \prime} \mathrm{E}\right)$. The weather is dry and hot in summer and cold and rainy in winter. The range of the rainfall is $535 \mathrm{~mm}$ and temperature degrees range from (-5.5) to $(48){ }^{\circ} \mathrm{C}$ (Directory of Meteorology and Seismology, 2019)

Different vegetables shown in Table (1) were selected from Domiz1 camp farms and analyzed for lead $(\mathrm{Pb})$, cadmium $(\mathrm{Cd})$, zinc $(\mathrm{Zn})$ and cobalt (Co) concentration in edible parts. These vegetables are commonly consumed by people there, and very highly relevant to human nutrition and health.

Table (1): Local, English and scientific name of Studied Vegetables

\begin{tabular}{cccc}
\hline No. & Local name & English name & Scientific name \\
\hline 1 & Bajansork & Tomato & Solanum lycopersicum \\
\hline 2 & Bajanreshk & Eggplant & Solanem melongena \\
\hline 3 & Flfl & Pepper & Capsicum annum \\
\hline 4 & Qulnde Zer & Pumpkin & Cucurbita moschata \\
\hline 5 & Qulnd Kosa & Squash & Cucrbita pepo \\
\hline 6 & Qulnde Silehi & Gourd & Abelmoschus esculentus \\
\hline 7 & Bamia & Okra &
\end{tabular}

\section{Collection and digestion of water samples}

In present study two set of water samples were taken, each with three replicates at 5 minutes interval. One sample was collected for determination of physical and chemical water properties-using polyethylene bottles and kept cold until reaching the lab, and the second one used for heavy metals determination, which stored in polyethylene bottles (pre-washed with a solution of nitric acid and water (1:1) and acidified by adding some drops of nitric acid to a $\mathrm{pH}$ below (2) in order to minimize the precipitation and adsorption of heavy metals on container walls.

Samples digested by adding $5 \mathrm{ml}$ of concentrated nitric acid $\left(\mathrm{HNO}_{3}\right)$ to $100 \mathrm{ml}$ of wastewater samples (APHA, 1958), and boiled to a possible smallest volume but not dryness, boiling of water samples continued until the water samples reached colorless stage. The digested samples diluted by distilled deionized water in a volumetric flask of $25 \mathrm{ml}$ to the mark. The diluted samples were filtered in a polyethylene bottles and stored at $4{ }^{\circ} \mathrm{C}$ until the analysis to be carried out.

\section{Collection and digestion of soil samples}

Three samples from top soil $(0-30 \mathrm{~cm})$ were collected from the farms irrigated by waste water. Air dried then crushed, sieved through 2-mm sieve and stored in polyethylene bags in order to be digested afterword.

Sieved soil samples were grounded finely by a handle mill. $0.5 \mathrm{~g}$ of grounded soil was weighted and digested in a 50-ml conical flask by adding $10 \mathrm{ml}$ of a mixture of sulfuric acid, nitric acid, and perchloric acid with a ratio of 3:1:1 respectively on a hot plate $\left(200^{\circ} \mathrm{C}\right)$ in the digestion chamber (APHA, 1958 Heating continued until a clear 
color obtained, then diluted with distilled deionized water in a 50-ml volumetric flask and filtered by the filter paper. Filtered solution stored in a polyethylene bottles and kept in the refrigerator until analysis.

\section{Collection and digestion of vegetables fruits}

Three replicates of the vegetables fruits were harvested from each plants when reached to maturity (field maturity), about one $\mathrm{kg}$ fresh fruit for each vegetable from different plants (which represent one replicate).

Collected fruits packed in a polyethylene bags and brought to the lab, rinsed very well by tap water then splashed genteelly with distilled water. All fruits were cut by a stainless knife to possible smallest volume pieces and air died for two days followed by oven drying at $70^{\circ} \mathrm{C}$ for $48 \mathrm{hrs}$. After that, dried samples were grounded by a handle mill in order to be ready for digestion.

Vegetable samples were digested according to the procedure used by (Tandon, 1999). $0.5 \mathrm{~g}$ of finely grounded powder was wet digested in a $100-\mathrm{ml}$ conical flask by adding $10 \mathrm{ml}$ mixture of nitric acid and perchloric acid in a ratio of 9:4 on a hot plate in the digestion chamber (fume hood). Heating and digestion continued until the liquid become colorless. The liquid further heated to the volume 2-3 ml, then lifted beside to lose the heat, then diluted by distilled deionized water in a 50 $\mathrm{ml}$ volumetric flask. Finally, the diluted sample filtered by the filter paper and stored in a polyethylene bottles for measuring heavy metals.

Measurement of heavy metals in water, soil and fruits

Concentration of lead, cadmium, zinc, and copper measured in the samples of water, soil, and fruits were measured by atomic absorption spectrophotometer type (SHIMADUZ 7000) in the labs of Directorate of the Environment of Duhok City, Kurdisatn Region-Iraq.

Bio concentration factor (BCF)

Biological accumulation factor was measured by the equation used by (Qu et al., 2011).

Where:

$$
B C F=\frac{P b \text { in plant }}{P b \text { in soil }}
$$

$\mathbf{P b}$ in plant is a $\mathrm{Pb}$ concentration $\left(\mu \mathrm{g} \cdot \mathrm{g}^{-1}\right.$ dray weight) in plant tissues (shoots, roots, or fruits)

$\mathbf{P b}$ in soil is a $\mathrm{Pb}$ content in the studied soil ( $\mu \mathrm{g} . \mathrm{g}^{-}$ 1)

\section{Daily intake}

Daily intake $\left(\mu \mathrm{g} \cdot \mathrm{kg}^{-1}\right)$ body weight of each heavy metal from eating recommended $0.40 \mathrm{~kg}$ of fresh vegetables in a day (Najagi et al., 2017) was calculated in respect to moisture content in fruits of studied vegetables (Table 2). The mean human body weight is considering $70 \mathrm{~kg}$.

Table (2): Percent of dry weight in $1 \mathrm{~kg}$ fresh fruits of studied vegetables.

\begin{tabular}{ccc}
\hline Vegetables & Moisture content (\%) & $\begin{array}{c}\text { Percent of dry weight in } 1 \mathrm{~kg} \text { fresh } \\
\text { weight }(\%)\end{array}$ \\
\hline Tomato & 95 & 5 \\
\hline Eggplant & 92 & 8 \\
\hline Pepper & 94 & 6 \\
\hline Pumpkin & 90 & 10 \\
\hline Squash & 95 & 5 \\
\hline Gourd & 92 & 8 \\
\hline Okra & 93 & 7 \\
\hline
\end{tabular}

*Calculated during the process of vegetables drying.

\section{Calculation of Daily Metal Intake}


The daily metal intake for each heavy metal from eating tested vegetables was calculated according to the following equation:
Daily Metal Intake (DMI) $\left(\mu \mathrm{g} . \mathrm{kg}^{-1}\right.$ body weight $)=$

$$
\left\{\begin{array}{c}
\left\{\frac{\text { Metal con. }\left(\frac{\mathrm{mg}}{\mathrm{kg}} \mathrm{D} . w \mathrm{wt}\right) * \text { Percent of dry weight in } 0.4 \mathrm{~kg} \text { fresh vegetable }(\text { table } 2)}{\text { body weight }(70 \mathrm{~kg})}\right. \\
* 1000 \mu \mathrm{g}
\end{array}\right.
$$

\section{Statistical Analysis}

The randomized completely block design (R.C.B.D.) was depended for statistical analyses (Al-Rawi and Khalaf-Alla, 2000), the Micro soft (SAS 2002) was used for data analysis. Analysis of variance (ANOVA) and the differences between various treatments means at 5\% level were tested with Duncan Multiple Range test (Duncan, 1955).

\section{RESULTS AND DISCUSSION}

Physical and chemical characteristic of irrigation water

Data showed in table (3) represent characteristic of wastewater used for irrigation of the studied vegetables. The chemical parameters measured in wastewater were $\mathrm{pH}$, electrical conductivity (EC), total dissolved solids (TDS), salinity, dissolved oxygen (DO), chemical oxygen demand (COD), biochemical oxygen demand (BOD), total nitrogen (TN), total phosphorous (TP), $\mathrm{Pb}, \mathrm{Cd}, \mathrm{Co}$, and $\mathrm{Zn}$.

As it was expected $\mathrm{pH}$ of wastewater (7.82) was within the tolerance limit $(6.5-8.5)$ of $\mathrm{pH}$ in irrigation water according to the standards recommended by (FAO, 1992). The value of EC was $\left(703 \mu \mathrm{s} . \mathrm{cm}^{-1}\right)$, which didn't exceed permissible limit of $\left(3000 \mu \mathrm{s} . \mathrm{cm}^{-1}\right)$, low EC of water means low salinity (Rattan et al., 2005).

Also DO (0.86 mg. $\left.\mathrm{l}^{-1}\right)$ and COD (108.6 mg. $\mathrm{l}^{-}$

$\left.{ }^{1}\right)$ were very low when compared with standard limits of $\left(9 \mathrm{mg} \cdot \mathrm{l}^{-1}\right)$ for DO and $\left(500 \mathrm{mg} \cdot \mathrm{l}^{-1}\right)$ for COD. While BOD $\left(217,2 \mathrm{mg} \cdot \mathrm{l}^{-1}\right)$ was more than twice the safe limit $\left(100 \mathrm{mg} . \mathrm{l}^{-1}\right)$ of BOD in irrigation water (FAO, 1992).

With regards to total nitrogen and total phosphorous content which are considered as a primary macronutrients for plant growth (ElBeshbeshy and Sheris, 1998), the results showed considerable amount of these two elements in waste water. It was found that the concentration of total $\mathrm{N}$ and $\mathrm{P}$ in irrigation water were lower than the prescribed limits (30 and $20 \mathrm{mg} \cdot \mathrm{l}^{-1}$ ) of $\mathrm{N}$ and $\mathrm{P}$ in respectively according to standards of (FAO 1985).

Concerning the heavy metals status in wastewater used for irrigation of studied vegetables, the results showed that the concentration of $\mathrm{Pb}, \mathrm{Cd}, \mathrm{Co}$, and $\mathrm{Zn}$ in irrigation water were $\left(0.001, \mathrm{ND}, 0.0015\right.$, and $\left.0.058 \mathrm{mg} . \mathrm{l}^{-1}\right)$ respectively.

Depending on the standards prescribed by (FAO, 1985 and FAO, 1992) for irrigation, it is obvious that concentration of these metals was lower than standard limits.

Table (3): Physical and chemical properties of wastewater used for the irrigation.

\begin{tabular}{cccc}
\hline Parameter & Unit & Value & Standards $^{*}$ \\
\hline PH & --- & 7.82 & $6.5-8.5$ \\
\hline EC & $\mu \mathrm{s.cm}{ }^{-1}$ & 703 & $<3000$ \\
\hline TDS & $\mathrm{mg.}^{-1}$ & 490 & 2000 \\
\hline DO & $\mathrm{mg.}^{-1}$ & 0.86 & $<9$ \\
\hline COD & $\mathrm{mg.l}^{-1}$ & 108.6 & $80-500$ \\
\hline BOD & $\mathrm{mg.l}^{-1}$ & 217.2 & 100 \\
\hline T.P. & $\mathrm{mg.l}^{-1}$ & 17.933 & 30 \\
\hline T.N. & $\mathrm{mg.l}^{-1}$ & 26 & 20 \\
\hline
\end{tabular}




\begin{tabular}{cccc}
\hline $\mathbf{P b}$ & $\mathrm{mg} . \mathrm{I}^{-1}$ & 0.001 & 2 \\
\hline $\mathbf{C d}$ & $\mathrm{mg} . \mathrm{I}^{-1}$ & $\mathrm{ND}$ & 0.01 \\
\hline $\mathbf{C o}$ & $\mathrm{mg} . \mathrm{I}^{-1}$ & 0.0015 & 0.05 \\
\hline $\mathbf{Z n}$ & $\mathrm{mg} . \mathrm{I}^{-1}$ & 0.058 & 2 \\
\hline
\end{tabular}

* Limits for irrigation water (FAO 1985 and1992)

\section{Physical and chemical characteristic of studied soil}

Concentration of heavy metals in agriculture soil (mg. $\mathrm{kg}^{-1}$ soil) in the studied area is represented in Table (4). Concentration of $\mathrm{Pb}, \mathrm{Cd}$, $\mathrm{Co}$, and $\mathrm{Zn}$ in soil was $6.8,0.8,9.0$, and 80.0 (mg.kg ${ }^{-1}$ soil) respectively. The extent of $\mathrm{Pb}, \mathrm{Cd}$, and $\mathrm{Zn}$ was within the safe limits of (25-500), (36), and (300-600) mg.kg-1 soil respectively according (WHO/FAO, 2007) standards. Co concentration in soil was also found to be within the safe range (1-40 mg. $\mathrm{kg}^{-1}$ soil) (Alloway, 1990). Accordingly this soil is suitable for growing and production of vegetables.

Table (4): Physical and chemical properties of the soil.

\begin{tabular}{|c|c|c|c|}
\hline No. & Soil Parameter & Value & Unit \\
\hline 1 & Electrical Conductivity (EC) & 0.427 & ds. $m^{-1}$ \\
\hline 2 & Sodium adsorption ratio & 0.48 & $\%$ \\
\hline 3 & Organic Material (O.M) & 9.20 & g. $\mathrm{kg}^{-1}$ \\
\hline 4 & Soil Texture Class & Clay & \\
\hline 5 & Sand & 70.98 & g. $\mathrm{kg}^{-1}$ \\
\hline 6 & Silt & 300.64 & g. $\mathrm{kg}^{-1}$ \\
\hline 7 & Clay & 610.40 & g. $\mathrm{kg}^{-1}$ \\
\hline 8 & $\mathrm{pH}$ & 8.4 & - \\
\hline 9 & Total nitrogen $(\mathrm{N})$ & 45.20 & $\mathrm{mg} \cdot \mathrm{kg}^{-1}$ \\
\hline 10 & Total phosphorous $(\mathrm{P})$ & 5.10 & $\mathrm{mg} \cdot \mathrm{kg}^{-1}$ \\
\hline 11 & Total potassium $(\mathrm{K})$ & 4.88 & $\mathrm{mg} \cdot \mathrm{kg}^{-1}$ \\
\hline 12 & Calcium Carbonate $\left(\mathrm{CaCO}_{3}\right)$ & 20.40 & $\%$ \\
\hline 13 & Cat ion exchange capacity(CEC) & 32.88 & $\mathrm{Cmol} .100 \mathrm{~g}^{-1}$ soil \\
\hline 14 & Total lead & 6.8 & $\mathrm{mg} \cdot \mathrm{kg}^{-1}$ \\
\hline 15 & Total cadmium & 0.8 & $\mathrm{mg} \cdot \mathrm{kg}^{-1}$ \\
\hline 16 & Total cobalt & 9.0 & $\mathrm{mg} \cdot \mathrm{kg}^{-1}$ \\
\hline 17 & Total zinc & 80 & $\mathrm{mg} \cdot \mathrm{kg}^{-1}$ \\
\hline
\end{tabular}

\section{Heavy metals concentration in fruits of studied vegetables}

Heavy metals concentration in fruits of studied vegetables irrigated with wastewater is shown in Table (5). Lead concentration fluctuated irregularly in fruits of tested vegetables, it ranged from $\left(3.73 \mathrm{mg} \cdot \mathrm{kg}^{-1}\right)$ to $\left(11.43 \mathrm{mg} \cdot \mathrm{kg}^{-1}\right)$ in squash and okra fruits respectively, that was differed significantly from all other treatments.

Lead known for its bad effects on human health-Exposure to $\mathrm{Pb}$ affects negatively on infants, reproductive system, liver, kidney, and stomach (Järp, 2003). Lead concentration in fruits of tomato, eggplant, and pepper which belong to family of Solanaceae ranged from (4.10-4.40 mg.kg-1 ${ }^{-1}$, which was more than $\mathrm{Pb}$ concentration $\left(0.168-0.532 \mathrm{mg} . \mathrm{kg}^{-1}\right)$ in same vegetables (Mosleh and Almagabig, 2013). However these results were in accordance with the results of (Demirezen and Aksoy 2006) who found (5.3-9.7 mg. $\left.\mathrm{kg}^{-1}\right)$ of $\mathrm{Pb}$ in same vegetables.

Lead concentration in fruits of Cukurbitraceae family vegetables; pumpkin, squash, and gourd ranged from $\left(3.73-3.99 \mathrm{mg} \cdot \mathrm{kg}^{-1}\right)$. These results were more than the results of (Antonious et al., 2010 and Zhou et al., 2016), but much lower than the results of (Ozores-Hampton et al., 1997 and Demirezen and Aksoy, 2006). The content of $\mathrm{Pb}$ in okra fruits that belong to family Malvaceae accumulated more significantly $\mathrm{Pb}$ than all other vegetables. The present results of $\mathrm{Pb}$ in okra fruits was slightly more than results of (Demirezen and 
Aksoy, 2006) who recorded (10.70 mg. $\left.\mathrm{kg}^{-1}\right)$ in fruits of okra, in other hand both of Abbass, et al., (2010) and Youssef and Eissa, (2015) found (0.064 and $\left.0.24 \mathrm{mg} \cdot \mathrm{kg}^{-1}\right)$ of $\mathrm{Pb}$ in fruits of okra irrigated with sewage water respectively. Results of $\mathrm{Pb}$ concentration in fruits of all tested vegetables were more than the safe limits of $\mathrm{Pb}$ in vegetables $\left(0.50-2.00 \mathrm{mg} \cdot \mathrm{kg}^{-1}\right)$ stated by world health organization and food and agriculture organization (WHO/FAO, 1976). Accumulation of $\mathrm{Pb}$ in fruits of vegetables might come from irrigation water, from soil, and/or from air pollution (Gorbounov et al., 2003 and Al-Enezi et al., 2004).

Like lead, cadmium is also a very toxic element to human and animals, it cause blood and heart diseases (WHO, 1987). The $\mathrm{Cd}$ concentration was $\left(0.28,0.33\right.$, and $\left.0.59 \mathrm{mg} . \mathrm{kg}^{-1}\right)$ in eggplant, pepper, and tomato respectively. These values were more than results of (Goboasa et al., 2010; and Bigdeli and Seilsepour, 2008), but noticeably smaller than (16.61 and 40.20 $\mathrm{mg} . \mathrm{kg}^{-1}$ ) of Cd in eggplant recorded by (Guo et al., 2013 and Topcuoĝlu and Önal, 2018) respectively; Perveen et al., (2012) recorded (8.4-61.4) and (9.70 mg. $\left.\mathrm{kg}^{-1}\right)$ of $\mathrm{Cd}$ in tomato and pepper respectively.

Fruits of pumpkin, squash, and gourd accumulated respectively $(0.22,0.22$, and 0.38 $\mathrm{mg} \cdot \mathrm{kg}^{-1}$ ) of $\mathrm{Cd}$. The present results of $\mathrm{Cd}$ were in line with the those of Ozores-Hampton et al., (1997), when they recorded $\left(0.29 \mathrm{mg} \cdot \mathrm{kg}^{-1}\right)$ of $\mathrm{Cd}$ in squash fruits. Correspondingly, very high $\mathrm{Cd}$ was accumulated by fruits of squash (41.60 mg. $\mathrm{kg}^{-1}$ ) (Perveen et al., 2012), and also in contrast to our data, slightly high Cd content $(0.60$ mg.kg-1) was noticed by Demirezen and Aksoy, (2006) in pumpkin fruits.

Fruits of okra accumulated $\left(0.51 \mathrm{mg} \cdot \mathrm{kg}^{-1}\right)$ of $\mathrm{Cd}$ in the present study, which was higher than results of (Opaluwa, et al. 2012) and (Youssef and Eissa, 2015) who obtained (0.07 and 0.27) mg.kg${ }^{1}$ of Cd respectively in fruits of okra, but it was in close to the $\left(0.58 \mathrm{mg} \cdot \mathrm{kg}^{-1}\right)$, results of (Demirezen and Aksoy, 2006). Cadmium introduced to the soil, water, and plants by human activities. However, no $\mathrm{Cd}$ concentration detected in irrigation water analyzed in present study but, still it presents in the soil about $0.8 \mathrm{mg} \cdot \mathrm{kg}^{-1}$ soil (Table 4), because it is more available than other heavy metals since it is more soluble in the soil (Järp,
2003). Also, Cd pollutes soils as impurities from phosphate fertilizers, in some studies about $7 \mathrm{ppm}$ of $\mathrm{Cd}$ detected in phosphorous fertilizers (Wild, 1994).

Plant growth not need only macronutrients in order to be healthy but also require essential micronutrients such as $\mathrm{Fe}, \mathrm{Cu}, \mathrm{Zn}, \mathrm{Co}, \mathrm{Ni}, \mathrm{Mn}$, Mo, Bo to complete its life cycle (Marschner, 2012). Cobalt naturally found throughout the environment and long-term exposure to Co cause asthma, fibrosis, liver and kidney congestion, and effect on heart (ATSDR, 1992).

The cobalt concentration in studied vegetables ranged from the $\left(0.22 \mathrm{mg} \cdot \mathrm{kg}^{-1}\right)$ in squash fruits to $\left(0.03 \mathrm{mg} \cdot \mathrm{kg}^{-1}\right)$ in pepper fruits. Few studies were conducted on the Co intake by plants. However, Bigdeli and Seilsepour, (2008) investigated Co contamination in some vegetables irrigated with wastewater, and found that the Co concentration in eggplant fruits was zero but the concentration of Co was $\left(0.01 \mathrm{mg} . \mathrm{kg}^{-}\right.$ ${ }^{1}$ ) in tomato fruits. In another study conducted by Opaluwa, et al., (2012) found that the concentration of Co in okra fruits was (0.02-0.28 $\left.\mathrm{mg} \cdot \mathrm{kg}^{-1}\right)$.

Zinc concentration, which is essential metal for plant growth was $(56.13,39.33$, and 53.83 $\mathrm{mg} \cdot \mathrm{kg}^{-1}$ ) in tomato, eggplant and pepper respectively. These results are in consistent with the results of Topcuoĝlu and Önal, (2018) as they found (29.0-228.0 mg. $\mathrm{kg}^{-1}$ ) of Cd in eggplant, and very similar to the results of Youssef and Eissa, (2015) when they detected (35-55 mg. $\mathrm{kg}^{-1}$ ) of $\mathrm{Zn}$ in fruits of tomato. On other hand a lower $\mathrm{Zn}$ accumulation was recorded by Gogoasa et al., (2010); $\left(5.0 \mathrm{mg} \cdot \mathrm{kg}^{-1}\right)$ in tomato, $\left(5.2 \mathrm{mg} \cdot \mathrm{kg}^{-1}\right)$ in eggplant, and $\left(6.4 \mathrm{mg} \cdot \mathrm{kg}^{-1}\right)$ in pepper.

The lower $\mathrm{Zn}$ held by pumpkin fruits, that stand on (38.83 mg. $\mathrm{kg}^{-1}$ ) (lower $\mathrm{Zn}$ content), while squash held $\left(62.67 \mathrm{mg} . \mathrm{kg}^{-1}\right)$ of $\mathrm{Zn}$, although gourd accumulated $\left(50.0 \mathrm{mg} \cdot \mathrm{kg}^{-1}\right) \mathrm{Zn}$ in the fruits, and okra fruits contained the uppermost $\mathrm{Zn}(65.70$ $\left.\mathrm{mg} \cdot \mathrm{kg}^{-1}\right)$. These results were higher as compared to those of Zhou et al., (2016) that show (2.88 mg.kg $\left.{ }^{-1}\right) \mathrm{Zn}$ in Pumpkin, and also to those of Mosleh and Almagabig, (2013) in squash (0.36 mg.kg ${ }^{-1}$ ). Regarding the $\mathrm{Zn}$ concentration in squash and okra, these results were in line with those of Youssef and Eissa, (2015), who found $\left(40-60 \quad \mathrm{mg} \cdot \mathrm{kg}^{-1}\right)$ and (35-60 mg. $\left.\mathrm{kg}^{-1}\right) \quad \mathrm{Zn}$ concentration in squash and okra, respectively. 
Table (5): Heavy metals concentration (mg.kg-1 d.wt) in studied vegetables irrigated with wastewater in Domiz1 camp.

\begin{tabular}{ccccc}
\hline \multirow{2}{*}{ Vegetables } & \multicolumn{4}{c}{ Heavy metals } \\
\cline { 2 - 5 } & Lead & Cadmium & Cobalt & Zinc \\
\hline Tomato & $9.40 \mathrm{ab}$ & $0.59 \mathrm{a}$ & $0.06 \mathrm{bc}$ & $56.13 \mathrm{ab}$ \\
\hline Eggplant & $4.10 \mathrm{c}$ & $0.28 \mathrm{~cd}$ & $0.15 \mathrm{ab}$ & $39.33 \mathrm{c}$ \\
\hline Pepper & $9.13 \mathrm{~b}$ & $0.33 \mathrm{bc}$ & $0.03 \mathrm{c}$ & $53.00 \mathrm{bc}$ \\
\hline Pumpkin & $3.87 \mathrm{c}$ & $0.22 \mathrm{~d}$ & $0.043 \mathrm{c}$ & $38.83 \mathrm{c}$ \\
\hline Squash & $3.73 \mathrm{c}$ & $0.22 \mathrm{~d}$ & $0.22 \mathrm{a}$ & $62.67 \mathrm{ab}$ \\
\hline Gourd & $3.99 \mathrm{c}$ & $0.38 \mathrm{~b}$ & $0.17 \mathrm{a}$ & $50.00 \mathrm{bc}$ \\
\hline Okra & $11.43 \mathrm{a}$ & $0.51 \mathrm{a}$ & $0.06 \mathrm{bc}$ & $65.70 \mathrm{a}$ \\
\hline Mean & 6.52 & 0.36 & 0.11 & 52.24 \\
\hline Safe limits & $0.50-2.00^{\star}$ & $0.02-1.00^{*}$ & $0.05-0.50^{\#}$ & $60.00^{\star}$ \\
\hline
\end{tabular}

* WHO/FAO 1976

\# Misra and Mani, 1991

\section{Bio concentration factor}

Bio concentration factor $(\mathrm{BCF})$ is a parameter illustrates the ability of plant to transfer the metals from the soil to plant. In (Table 6) BCF ranged from (0.549-1.681) for $\mathrm{Pb},(0.271-0.733)$ for $\mathrm{Cd}$, (0.003-0.19) for Co, and (0.485-0.821) for $\mathrm{Zn}$.
The $\mathrm{BCF}$ value of $\mathrm{Pb}(1.681)$ was more than results of (Yadav et al., 2013). In current study, the minimum value of $\mathrm{BCF}$ was found for Co (0.003) in fruits of pepper. The values of BCF for measured heavy metals in studied vegetables were in order of $\mathrm{Pb}>\mathrm{Zn}>\mathrm{Cd}>\mathrm{Co}$.

Table (6): Bio concentration factor of heavy metals in studied vegetables irrigated with wastewater in

Domiz1 camp.

\begin{tabular}{ccccc}
\hline Vegetables & \multicolumn{4}{c}{ Bio concentration factor } \\
\cline { 2 - 5 } & Lead & Cadmium & Cobalt & Zinc \\
\hline Tomato & $1.382 \mathrm{ab}$ & $0.733 \mathrm{a}$ & $0.007 \mathrm{bc}$ & $0.702 \mathrm{ab}$ \\
\hline Eggplant & $0.603 \mathrm{c}$ & $0.350 \mathrm{~cd}$ & $0.017 \mathrm{ab}$ & $0.492 \mathrm{c}$ \\
\hline Pepper & $1.343 \mathrm{~b}$ & $0.413 \mathrm{bc}$ & $0.663 \mathrm{ab}$ \\
\hline Pumpkin & $0.569 \mathrm{c}$ & $0.271 \mathrm{~d}$ & $0.003 \mathrm{c}$ & $0.485 \mathrm{c}$ \\
\hline Squash & $0.549 \mathrm{c}$ & $0.283 \mathrm{~d}$ & $0.025 \mathrm{a}$ & $0.783 \mathrm{ab}$ \\
\hline Gourd & $0.587 \mathrm{c}$ & $0.475 \mathrm{~b}$ & $0.019 \mathrm{a}$ & $0.625 \mathrm{bc}$ \\
\hline Okra & $1.681 \mathrm{a}$ & $0.638 \mathrm{a}$ & $0.007 \mathrm{bc}$ & $0.821 \mathrm{a}$ \\
\hline Mean & 0.959 & 0.452 & 0.012 & 0.653 \\
\hline
\end{tabular}

\section{Maximum daily intake}

In present study the maximum daily intake (MDI) of $\mathrm{Pb}, \mathrm{Cd}, \mathrm{Co}$, and $\mathrm{Zn}$ from each studied vegetables were calculated from eating recommended daily intake of vegetables (400g/day) (Najagi et al., 2017).

Table (7) shows that the MDI range of heavy metals in tested vegetables was as follow; for $\mathrm{Pb}$ it was (0.381-1.633 $\mu \mathrm{g} . \mathrm{kg}^{-1}$ body weight), for $\mathrm{Cd}$ it was $\left(0.023-0.073 \mu \mathrm{g} . \mathrm{kg}^{-1}\right.$ body weight), for Co it was(0.003-0.028 $\mu$ g.kg ${ }^{-1}$ body weight), whereas concerning $\mathrm{Zn}$, it was (5.728 -
$9.381 \mu \mathrm{g} . \mathrm{kg}^{-1}$ body weight). The values of MDI of studied heavy metals were in order of $\mathrm{Zn}>\mathrm{Pb}$ $>\mathrm{Cd}>\mathrm{Co}$. The fruits of vegetables grown in Domiz 1 camp that irrigated with wastewater had a DMI of $\mathrm{Pb}, \mathrm{Cd}, \mathrm{Co}$, and $\mathrm{Zn}$ below the provisional tolerable daily intake (4.00 and 1.00 $\mu \mathrm{g} . \mathrm{kg}^{-1}$ body weight) for $\mathrm{Pb}$ and $\mathrm{Cd}$ respectively (WHO, 1987). (250.00 $\mu \mathrm{g} \cdot \mathrm{kg}^{-1}$ body weight) for Co (Najagi et al., 2017); and (143.00 $\mu \mathrm{g} . \mathrm{kg}^{-1}$ body weight) for $\mathrm{Zn}$ (WHO, 1982).

Depending on the daily intake values of $\mathrm{Pb}$, $\mathrm{Cd}$, Co, and $\mathrm{Zn}$, and in comparison with 
(Provisinal tolerable daily intake) PTDI of four metals a person of $70 \mathrm{~kg}$ body weight could safely consume $400 \mathrm{~g}$ of studied vegetables per day (Table6).

Table (7): Daily intake ( $\mu \mathrm{g} . \mathrm{kg}^{-1}$ body weight) from eating one $\mathrm{kg}$ of fresh vegetables.

\begin{tabular}{|c|c|c|c|c|}
\hline \multirow[t]{2}{*}{ Vegetables } & \multicolumn{4}{|c|}{ Daily intake (Based on an adult of $70 \mathrm{~kg}$ ) } \\
\hline & Lead & Cadmium & Cobalt & Zinc \\
\hline Tomato & $0.959 \mathrm{bc}$ & $0.060 \mathrm{~b}$ & $0.007 \mathrm{~b}$ & $5.728 \mathrm{c}$ \\
\hline Eggplant & $0.669 \mathrm{~cd}$ & $0.046 \mathrm{c}$ & $0.025 \mathrm{a}$ & 6.422 bc \\
\hline Pepper & $1.118 b$ & $0.040 \mathrm{c}$ & $0.003 \mathrm{~b}$ & $6.490 \mathrm{bc}$ \\
\hline Pumpkin & $0.789 \mathrm{c}$ & $0.044 \mathrm{c}$ & $0.009 \mathrm{~b}$ & $7.925 a b$ \\
\hline Squash & $0.381 \mathrm{~d}$ & $0.023 \mathrm{c}$ & $0.023 \mathrm{a}$ & $6.395 \mathrm{bc}$ \\
\hline Gourd & $0.651 \mathrm{~cd}$ & $0.062 b$ & $0.028 \mathrm{a}$ & $8.163 a b$ \\
\hline Okra & $1.633 \mathrm{a}$ & $0.073 \mathrm{a}$ & $0.009 \mathrm{~b}$ & $9.381 \mathrm{a}$ \\
\hline mean & 0.886 & 0.050 & 0.015 & 7.215 \\
\hline $\begin{array}{c}\text { Provisional tolerable } \\
\text { daily intake }\end{array}$ & $4.0 *$ & 1.00 * & $250.00 * *$ & $143.00 * * *$ \\
\hline
\end{tabular}

*(WHO, 1987), **(Najagi et al., 2017), ***(WHO, 1982)

\section{CONCLUSION}

Depending on the results of the study it can be concluded that the levels of $\mathrm{Pb}, \mathrm{Cd}, \mathrm{Co}$, and $\mathrm{Zn}$ in soil and irrigation water was within the safe limits, therefore the soil is suitable for growing vegetables, but the irrigation water must be subjected to some treatments such primary treatment to reduce the values of $\mathrm{EC}, \mathrm{BOD}$, and total nitrogen. However, the daily intake values of all studied metals were within the safe limits, but the concentration of $\mathrm{Pb}$ exceeded the maximum permissible levels in vegetables.

\section{REFERENCES}

A T S D R (Agency for Toxic Substances and Disease Registry). (1992). Toxicological profile for cobalt. Public health service.USD Dept. Of Health and Human Services, Public Health services. Atlanta, GA.

Abbas, M., Z., Parveen, M., Iqbal, Riazuddin, S., Iqbal, M., Ahmed, and Bhutto, R., (2010). Monitoring of toxic metals (cadmium, lead, arsenic and mercury) in vegetables of Sindh, Pakistan. Kathmandu university journal of science, engineering and technology, 6(11):6065.

Al-Enezi, G; Hamoda, M. F; and Fawzi, N. (2004). Heavy metal concentrations of municipal wastewater and sludge in Kuwait. J. of Environ. Sci. and Health. A39 (2): 397-407.
Ali1 H., M. Naseer, and Sajad, M. A., (2012). Phytoremediation of heavy metals by Trifolium alexandrine. International Journal of Environmental Sciences, 2 (3): 1459 - 1469.

Alloway, B. J., (1990). Heavy metals in soils. John Wiley and Sons, Inc. New York, ISBN 047021584

Al-Rawi, K. M. and A. Khalafalla (2000). Analysis of Experimental Agriculture Disgen. Dar AlKutub for Printing and Publishing. Mosul Univ. (In Arabic).

Antonious, G.F. , J. C., Snyder, and Dennis, S. O., (2010). Heavy metals in summer squash fruits grown in soil amended with municipal sewage sludge. J. Environ Sci Health B., 45(2):167173.

APHA (American Public Health Association), Jakson, M. L. (1958). Soil chemical analysis. Ed. Prentice Hall. Inc. Englawood Chiffs, New Jersey, U. S. A. (1989). Standard methods for the examination of water and waste water analysis, American Public Health Association, Washington, DC, USA.

Avci, H., (2013). Heavy metals in vegetables irrigated with wastewater in Gaziantep, Turkey: A review of cause and potential for human health. Fresenius Environmental Bulletin, 22(1):146151.

Bigdeli, M., and Seilsepour, M., (2008). Investigation of metals accumulation in some vegetables irrigated with waste water in Shahre Rey-Iran and toxicological implication. AmericaEurasian J. Agric. \& Environ. Sci., 4(1):86-92.

Bowen, H. J. H. (1966). Trace Elements in 
biochemistry. Academic Press, London.

BRHA (Board of Relief and Humanitarian Affairs), (2019). Executive Directorate management of Domiz 1 Camp, Duhok Governorate, Kurdistan Region-Iraq.

Demirzen, D. and Aksoy, A. (2006). Heavy metal levels in vegetables in Turkey are within safe limits for $\mathrm{Cu}, \mathrm{Zn}, \mathrm{Ni}$ and exceed for $\mathrm{Cd}$ and $\mathrm{Pb}$. Journal of food quality, 29 (3):252-265.

Directory of Meteorology and Seismology . Duhko, Kurdistan Region-Iraq 2019.

Duncan, D. B. (1955). Multiple Range and multiple F. tests. Biometrics, 11: 1-42.

El-Beshbeshy, T. R., and Sheris, M. A. (1998). Principles of plant nutrition (1st edition). House of Egyptian Universities- Cairo.viron. 109:310-322.

FAO, (1985). Guidelines: Lead evaluation for irrigated agriculture. Soils Bulletin 55. Food and Agriculture Organization of the United Nations, Rome, Italy.

FAO, (1992). Wastewater treatment and use in agriculture. In Pescod. M. B. (Ed.). Irrigation and drainage. Paper 47. FAO, Rome.

FAO/WHO, (1976). List of maximum levels recommended for contaminants by the joint FAO/WHO codex Aimenatarias Commission. $2^{\text {nd }}$ series, CAC/FAL, 3:1-8.

Fytianos, K., G., Katsianis, P., Trintafyllow, and Zachariadis, G., (2001). Accumulation of heavy metals in vegetables grown in an industrial area in relation to soil. Bull. Environ. Contam. Toxicol; 67: 423-430.

Gogoasa, I., G., Oprea, M., Harmanescu, T. I., Trasca, A., Rivis, and Gergen, I., (2010). Some metals ( $\mathrm{Fe}, \mathrm{Mn}, \mathrm{Cu}, \mathrm{Pb}$, and $\mathrm{Cd}$ ) content in vegetables from nonpolluted plain area of Cenad-Banat (Romani). Food and Environment SafetyJournal of Faculty of Eood Engineering, Stefancel Mare Univerity- Suceava, year IX, No.4.

Gorbounov, A. V; Frontasyeva, M. V; Kistanov, A. A; Lyapunov, S. M; Okina, O. and Ramadan, A. B. (2003). Heavy and toxic metals in staple foodstuffs and agriproduct from contaminated soils. J. Environ. Sci. Health, B38: 181-192.

Guo, Y., H., Feng, C., Chen, C., Jia, F., Xiong, and Lu, Y., (2013). Heavy metal concentration in soil and agriculture products near an industrial district. Pol. J. Environ. Stud., 22(5):13571362.

Intawongse, M., and Dean, J. R., (2006). Uptake of heavy metals by vegetable plants grown on contaminated soil and their bioavailability in the human gastrointestinal tract. Food additive and contaminants, 23(1).

Järp, L., (2003). Hazards of heavy metal contamination. British Medical Bulletin, 68 (1):167-182.

Kumar, P., and Chandra, R. (2004). Detoxification of distillery effluent through Bacillus thuringiensis (MTCC 4714) enhanced phytoremediation potential of Spirodela polyrrhiza (L.) Schliden. Bulletin of Environmental Contamination and Toxicology, 73(5), 903-910.

Lasat, M. M., (2000). Phytoextraction of metals from contaminated soil: a review of plant/soil/metal interactions and assessment of pertinent agronomic issues. Journal of Hazardous Substance Research 2: 1-25.

Marschner, H., (2012). Mineral nutrition of higher plants, $3^{\text {rd }}$ Ed. London: Acadmic Press:889.

Misra, S. G., Mani, D., (1991). Soil pollution. Ashish Publishing House. Punjabi Bagh. Mohamed, I.R. Tia, N.A., Khelefa, M. M., (2004). Soil sampling power for Iron as affected by cropping periods. Zagazig J. Agric. Res 31 (1), pp: 181-200.

Mosleh,Y. Y. I., and Almagrabi, A., (2013). Heavy metal accumulated in some vegetables irrigated with some wastewater .IJGHC, 2(1):81-90.

Najagi, J. M., N. A., Daniel,M.M., Najagi, P.N., Ngui, M.N, and Najagi, E.M.N., (2017). Heavy metals concentration in vegetables grown around dumpsites in Nairobi ciry, Kenya. World Environment, 7(2):49-56.

Opaluwa, O. P., M. O., Aremu, L. O., Ogbo, K. A., Abiola, I. E., Obdiba, M. M., Abubakar, and Neweze, N. O., (2012). Heavy metal concentration in soil, plant leaves and crops grown around dump sites in Lafia Metropolis, Nasarawa State, Nigeria. Advances in Applies Science Research, 3(2):780-784.

Ozores-Hamptona, M., Hanlonb, V., Bryanc, H., and \& Bruce S. (1997). Cadmium, Copper, Lead, Nickel and Zinc Concentrations In Tomato and Squash Grown In MSW Compost-amended Calcareous Soil. Compost Science \& Utilization, 5(4): 40-45.

Parsons. (2003). Trace element loading analysis. Santa Rosa Incremental Recycled waters Program.

Perveen, S., A., Samad, W., Nazif, and Shan, S., (2012). Impact of sewage water on vegetables qulity with respect to heavy metals in Peshawar Pakistan. Pak. J. Bot., 44(6):1923-1931.

Qu, J., C. Q. X., Lou1, X., Yuan, X. H., Wang, Q. Cong, and Wang, L., (2011). The effect of 
sodium hydrogen phosphate/citric acid mixtures on phytoremediation by alfalfa \& metals availability in soil. J. Soil Sci. Plant Nutr., 11(2): 85 - 95.

Rattan, R. K., Datta, S. P., Chhonkar, K., and Singh, A. K., (2005). Long-term impact of irrigation with sewage effluents on heavy metal content in soil, crops, and groundwater-a case study. Agric. Ecosyst. En

Song, Y. F., Wilke, B.-M., Song, X. Y., Gong, P., Zhou, Q. X., and Yang, G. F. (2006). Polycyclic aromatic hydrocarbons (PAHs), polychlorinated biphenyls (PCBs) and heavy metals (HMs) as well as their genotoxicity in soil after long-term wastewater irrigation. Chemosphere, 65(10), 1859-1868.

Tandon, H. (1999). Methods of analysis of soils, plants, water and fertilizers. Fertilisers Development and Consulation, New Delhi India, pp.144.

Topcuoĝlu, B., and Önal, M. K., ( 2018). Heavy metals accumulation in eggplant (Solanum melongena) grown in compost applied soil. Bulent Topocuglu, 2018.

WHO, (1987). Air quality for Europe. Number23. Europe, Copenhagen.
WHO, World Health Organization, (1982). Evaluation of certain food additives and contaminants. Twenty - Six report of the joint FAO/WHO expert committee on food additives. Technical Report Series No. 683: WHO, Geneva.

WHO/FAO, (2007). Joint FAO/WHO Food standard program codex alimentarious commission $13^{\text {th }}$ session. Report of the thirty eight session of codex committee on food hygiene, Houstan, United States of America, ALINORM 07/30/13.

Wild, A. (1994). Soil and the environment: An introduction. Cambredige University press.

Yadav, A., Yadav, P. K.., and Shukla, D. N. (2013). Investigation of heavy metals status in soil and vegetables grown in urban area of Allahabad, Uttar Pradersh, India. International Journal of Scientific and Research Publications, 3(9):1-7.

Youssef, M. A., and Eissa, M. A., (2015). Heavy metals accumulation in edible vegetables grown on contaminated soils. Egypt. J. Soil Sci.

Zhou, H., W., Yang, X., Zhou, L., Liu, J., Gu, W., Wang, J., Zou, T., Tian, P., Peng, and Liao, B., (2016). Accumulation of heavy metals in vegetable species planted in contaminated soils and the health risk assessment. Int $\mathrm{J}$ Environ Res Public Health, 13(3):289. 